\title{
НАКОПИЧЕННЯ ДОСВІДУ СЕНСОРНОГО РОЗВИТКУ ДІТЕЙ У СТАРОДАВНІ ЧАСИ
}

Барбашова I. А. Накопичення досвіду сенсорного розвитку дітей у стародавні часи.

У статті схарактеризовано еволюиію проблеми сенсорного розвитку дітей у стародавні часи (зародження виховання - IV cm.), здійснено аналіз перших філософських обтрунтувань значення сприймання в пізнанні навколишньої дійсності, розкрито змістовий $і$ організаційнометодичний потенціал цілеспрямованого навчання школярів перцепиіï.

Ключові слова: особистість, розвиток, сприймання, освіта, школа, учні, навчання, зміст, методи, засоби, форми.

Барбашова И. А. Накопление опыта сенсорного развития детей в древнейшие времена.

В статье охарактеризована эволюиия проблемы сенсорного развития детей в древнейшие времена (зарождение воспитания - IV cm.), проанализированы первые философские обоснования значения восприятия в познании окружающей действительности, раскрыты содержательный и организационно-методический потенциал целенаправленного обучения школьников перцепции.

Ключевые слова: личность, развитие, восприятие, образование, школа, учащиеся, обучение, содержание, методы, средства, формы.

Barbashova I. A. The accumulation of experience children's sensory development in ancient times.

The article deals with evolution of children's sensory development in ancient times (the emergence of education - IV century), analysis first philosophical justification of value in understanding perception of reality, revealed substantial organizational and methodological potential of purposeful pupil learning perception.

Key words: personality, development, perception, education, school, pupils, study, content, methods, tools, forms.

Постановка проблеми у загальному вигляді. Проблема сенсорного розвитку особистості в молодшому шкільному віці постала перед дидактикою наприкінці XX століття, тому важливою умовою іiї всеохопного усвідомлення $\epsilon$ вивчення світового досвіду початкового навчання та здобутків педагогічної думки з найдавніших часів.

Аналіз останніх досліджень і публікацій. Аналіз вітчизняних та зарубіжних історико-педагогічних джерел (Л. Артемова, О. Джуринський, І. Зайченко, В. Кравець, М. Левківський, Л. Медвідь, А. Сбруєва, О. Сухомлинська, Ф. Хофман, М. Ярмаченко та інші) надає змогу визначити різні аспекти підготовки молоді до життя у первісному суспільстві та функціонування шкільної освіти в епоху стародавнього світу, проте питання вдосконалення чуттєвої сфери особистості не знайшли належного відображення i потребують окремого вивчення.

Мета статті полягає у визначенні еволюційних тенденцій організації сенсорного розвитку дітей у стародавні часи.

Виклад основного матеріалу. Формування в молоді процесів сприймання в епоху становлення первісного людського суспільства було підпорядковано умовам природного виживання, відбувалось стихійно, 
шляхом наслідування конкретних форм людської життєдіяльності (полювання, риболовлі, готування їжі, виробництва знарядь праці, посуду і примітивного одягу, облаштування житла, спілкування, відправлення релігійних ритуалів, пісенно-танцювальних дій тощо). Мірою зростання продуктивних сил, ускладнення людських знань перцептивний розвиток дітей стає органічною складовою розумового виховання, яке відокремлюється від фізичної праці та набуває функції, що існує одвічно, передавати новим поколінням накопичений соціальний досвід.

Орієнтуванню у властивостях предметів і явищ дійсності навчали в ці часи в перших закладах із підготовки до життя i праці - своєрідних «будинках молоді» [1, с.9]. Спираючись на дані історико-педагогічних досліджень щодо особливостей функціонування таких прообразів шкіл, можна констатувати, що завдання перцептивного розвитку дітей полягали в удосконаленні багатьох відчуттів, принаймні зорових, слухових, дотикових, смакових, нюхових, i реалізовувались через опанування вихованцями зв’язного мовлення, усної творчості роду i племені, різних видів протописемності (наприклад, предметного письма - «вампум», «кіпу», - за якого носіями інформації слугували колір, форма, взаємне розташування i кількість мушелів, ниток і вузлів, а згодом - піктографічного письма, коли потрібні відомості передавались за допомогою зорових образів, фігур, схем, спрощених та узагальнених зображень), основ образотворчого і музичного мистецтва, трудових навичок.

Методи навчання сприймання полягали в демонструванні різноманітних властивостей предметів оточення та способів дії 3 ними, багаторазовому вправлянні та ігрових діях із розрізнення та відтворювання зовнішніх якостей об'єктів сприймання. Як засоби вдосконалення чуттєвих процесів дитини застосовувались різноманітні іграшки-брязкальця, тріскачки, свищики, фігурки тварин і птахів, кульки, дзиги, предмети побуту, зброя тощо [1, с. 19]. Організаційними формами транслювання культури взагалі та сенсорної зокрема були навчальні заняття, ритуалізовані обряди.

Зміст і методика перцептивного розвитку набули поширення та поглиблення в епоху стародавнього світу, територіальні та часові межі якого охоплюють існування цивілізацій Давнього Сходу (Шумер, Аккада, Вавилон, Ассирія, Сгипет, Індія, Китай, Персія та ін.) та античної Свропи Стародавньої Греції (Спарта, Афіни), Північного Причорномор'я і Приазов'я, (Ольвія, Тіра, Херсонес, Пантікапей, Фанагорія, Танаїс), Стародавнього Риму. Незважаючи на певну ізольованість, цим країнам була притаманна принципова єдність підходів до навчання молоді сприймання: удосконалення чуттєвих процесів учнів здійснювалося в умовах шкільної освіти, яка функціонувала під патронатом держави i поступово набула статусу стимулятора соціального прогресу.

Так, у школах Шумеру (III тис. до н. е.) переважну більшість з усього переліку дисциплін складали навчальні предмети, що мали значний потенціал для розвитку відчуттів учнів, а саме: мови (шумерська, аккадська), 
геометрія, астрономія, музика та співи; окрім цього, діти мали оволодіти вміннями вимірювати земельні ділянки, добре розрізняти тканини, метали i рослини. Особливе значення надавалось навчанню учнів письма: діти вирізали клинопис дерев'яним різцем на сирій глиняній плакетці, яку потім обпалювали. Система клинопису була складною, нараховувала близько 600 знаків і становила комбінування вертикальних i горизонтальних рисок. Пізніше у школах стали використовувати дерев'яні таблички: їх покривали тонким прошарком воску, на якому видряпували письмові знаки.

У Давньому Сгипті (III тис. до н. е.) існувало кілька типів спеціалізованих шкіл - для жерців, писців, музикантів, службовців, лікарів, ремісників. Більш дослідженими в історії педагогіки виявились школи жерців [7, с. 15]. Найефективнішим для сенсорного розвитку було навчання учнів ієрогліфічного письма, читання, іноземних мов, астрономії, математики, основ географії в поєднанні із геометрією (для формування вмінь малювати план місцевості), відправлення релігійних культів. Питому вагу при цьому займало засвоєння грамоти, а саме каліграфічної техніки зображення ієрогліфів: учням потрібно було запам'ятати до 700 знаків, розрізнювати їхню спрощену і класичну форму; основним матеріалом для письма спочатку були керамічні плакетки, шкіра та кістки тварин, а згодом - папірус; ієрогліфи зображували очеретяною паличкою, основний текст писали сажею, для пунктуаційних знаків і виокремлення смислових фраз застосовували вохру.

Перші школи Давньої Індії(III тис. до н. е.) багато в чому нагадували шумерські: розвиток перцептивних процесів учнів здійснювався переважно під час оволодіння ними навичками письма на пальмових листках, про що свідчать знайдені печатки зі своєрідними написами, глиняні чорнильниці. 3 унормуванням кастового ладу суспільства (II-I тис. до н. е.) програми шкільного навчання диференціюються відповідно до соціального розподілу. Так, у школах брахманів (жерців) удосконаленню сенсорики учнів сприяло опанування письма, читання (переважно священних ведичних текстів), математики, астрономії, різних мистецтв; у школах кшатріїв (військової знаті) якісне сприймання було умовою володіння зброєю, їзди верхи, виконання гімнастичних вправ, засвоєння математики, поезії, музики і танців (діти найнижчих каст зазвичай шкільну освіту не здобували).

У буддійський період (із середини I тис. до н. е.) освітня система набуває двоступеневого характеру - функціонують початкові («толь») i повні («аграхар») школи, останні були наче співтовариствами гуру й учнів; високий сенсорно-розвивальний ефект мало навчання санскриту (літературно обробленої форми давньоіндійської мови), місцевих мов, географії, математики, ліплення, живопису й інших мистецтв.

У Давньому Китаї (III тис. до н. е.) навчальні заклади були представлені загальноосвітніми («сян») i спеціалізованими військовими школами («сюй») або їх інтегративними формами («сюе» від «учити», «вчитесь»). Зміст освіти, який мав певний потенціал для розвитку в учнів процесів сприймання, складали, щонайменше, п’ять iз шістьох видів 
мистецтв: музика, письмо, стрільба із лука, лічба, верхова їзда (шостим видом мистецтва була мораль). Найголовнішою практичною метою в китайській педагогічній традиції уважалось засвоєння ієрогліфічного письма, яке нараховувало кілька десятків тисяч знаків. Відомо, що для цього застосовували розщеплений бамбук, зв'язаний у пластини, а також шовк, на яких писали соком лакового дерева за допомогою загостреної бамбукової палички; пізніше стали писати на папері тушшю і волосяним пензликом.

Педагогічну ментальність класичних давньогрецьких цивілізацій започаткували дві освітні моделі - спартанська й афінська (VI-IV ст. до н. е.). Перцептивний розвиток спартанців звичайно був підкорений ідеалу формування мужньої, духовно і фізично сильної людини, здійснювався у воєнізованих інтернатах, переважно за допомогою гімнастичних вправ, меншою мірою - через навчання грамоти (читання, письма), лічби, музики (цим дисциплінам не надавалось пріоритетного значення, їх засвоєння мало утилізований характер). Відповідно до афінської системи виховання діти мали можливість відвідувати (одночасно і послідовно) музичні та гімнастичні школи. У музичних школах молодші школярі здобували літературну i музичну освіту, часто синкретичним способом: через декламування уривків поетичних творів із паралельною грою на кіфарі - музичному щипковому інструменті. Опанування грамоти здійснювалось на буквоскладальній основі (назви окремих літер синтезувались у склади, потім - у слова); для письма використовували навощені дошки, на які учні паличками - «стилями» наносили букви. Окрім цього, до програми навчання було включено арифметику, геометрію та малювання. У гімнастичних школах, або палестрах, удосконаленню перцептивних процесів безпосередньо сприяли метання диска і списа, фехтування, військові ігри тощо.

Система шкільної освіти Давнього Риму склалася в VI-I ст. до н. е. На iii структурі суттєво позначилось соціально-класове розшарування населення: для дітей бідноти існували елементарні (тривіальні) школи, сенсорний розвиток у них забезпечувався в ході навчання молодшого покоління читати, писати і рахувати; діти привілейованих верств виховувались у граматичних школах, сприймання учнів формувалось під час вивчення латинської та грецької мов, риторики. Звернемо увагу на те, що з переліку предметів, які викладались у римських школах, майже зовсім були виключеними фізичне виховання і музика, що відповідало поширеному в той час уявленню про практичну спрямованість, «корисність» освіти, проте значно збіднювало можливості перцептивного розвитку дітей.

Стародавні цивілізації, окрім освітніх систем, надали світу немало філософських теорій, у надрах яких зародилися перші наукові обгрунтування значення процесів сприймання в пізнанні навколишньої дійсності та у загальному розумовому розвитку дитини. Наприклад, Геракліт (540-480 pp. до н. е.) творець античної діалектики - висловлював думки про те, що найважливішими знаряддями пізнання є відчуття і розум: завдяки органам відчуття учень вступає в контакт із довкіллям і набуває здатності мислити [4, 
с. 118]. Дотримуючись матеріалістичних поглядів на світ і людину, Демокріт (460-370 pр. до н. е.) уважав чуттєвий досвід початком пізнання, тобто «невиразним пізнанням», яке можна пояснити мисленням [4, с. 119].

Багато видатних філософів давнини (усі вони до того ж були вчителями, навіть засновниками шкіл) - Конфуцій (551-479 рр. до н. е.), Платон (427-347 pр. до н. е.), Арістотель (384-322 рр. до н. е.), Квінтіліан (42-118 рр. н. е.), Плутарх (46-120 рр. н. е.) - визначили у своїх творах загальні підходи до відбору змісту початкового навчання, питома вага якого мала величезний потенціал для сенсорного розвитку школярів. Це опанування письма, читання, геометричного матеріалу, співів, техніки гри на музичних інструментах і танців, гімнастики, військових умінь (стрільби 3 лука, метання дротиків тощо), малювання.

Висновки. Отже, у стародавню добу вдосконалення чуттєвої сфери молодших учнів набуває специфічності: 1) загальну мету сенсорного розвитку молодших школярів утворювали три провідні цільові напрями піднесення зорового, слухового і дотикового сприймання; формування ж нюхових і смакових відчуттів стає прерогативою сімейного виховання; 2) започатковуються філософські засади усвідомлення сутності перцептивних процесів і їх значення в пізнанні предметів і явищ оточення; 3) сукупність методів сенсорного розвитку складали словесні настанови, наслідування дій вчителя, вправи, активні ігри, змагання; рекомендувалося враховувати здібності школярів, заохочувати їх проханнями і похвалами (Квінтіліан, наприклад, радив застосовувати для цього своєрідні нагороди вирізані зі слонової кості літери або інші предмети, які дитина «із задоволенням обмацувала б, роздивлялась, називала» $[5$, с. 25]); 4) навчання школярів розрізняти зовнішні властивості предметів i явищ дійсності організовувалось на поліпредметній основі: для формування зорового просторового сприймання найефективнішими стають такі навчальні предмети і види діяльності, як письмо (клинопис, ієрогліфічне), геометрія, астрономія, гімнастичні та військові вправляння, вимірювання земельних ділянок; для кольорового - малювання, різнокольорове зображення письмових знаків; розвитку мовленнєвого слуху сприяло засвоєння фонетичних систем кількох мов, читання, ораторські декламування; музичний слух удосконалювався у співах, інструментальній грі, танцях, відправленнях релігійних культів; дотикові відчуття формувались через обстеження матеріалів для письма (глини, папірусу, бамбуку, шовку, пальмового листя, паперу), розрізнення тканин, металів, рослин; 5) формування перцептивних процесів особистості здійснювалось паралельно в умовах шкільної освіти і засобами сімейного виховання, яке традиційно охоплювало привілейованих дівчаток та більшість дітей незнатного походження.

Перспективи подальших пошуків у напрямку дослідження полягають у висвітленні специфіки організації сенсорного розвитку молодших школярів у подальші історичні періоди. 


\section{Література}

1. Артемова Л. В. Історія педагогіки України : [підруч. для студ. вищ. пед. навч. закл.] / Любов Вікторівна Артемова. - К. : Либідь, 2006. - 424 с.

2. Барбашова I. А. Загальна характеристика сенсорного розвитку в молодшому шкільному віці / I. А. Барбашова // Педагогічний дискурс : [3б. наук. праць / гол. ред. I. М. Щоробура]. - Хмельницький : Балюк І. Б., 2011. - Вип. 10. - С. 33-39.

3. Джуринский А. Н. История педагогики : [учеб. пособ. для студ. педвузов]/ Александр Наумович Джуринский. - М. : ВЛАДОС, 2000. - 432 с.

4. Зайченко І. В. Історія педагогіки : [навч. посіб. для студ. вищ. навч. закл.] : у 2 кн. / Іван Васильович Зайченко. - К. : Слово, 2010. - Кн. I : Історія зарубіжної педагогіки. 2010. $-624 \mathrm{c}$.

5. Зайченко I. В. Історія педагогіки : [навч. посіб. для студ. вищ. навч. закл.] : у 2 кн. / Іван Васильович Зайченко. - К. : Слово, 2010. - Кн. II : Школа, освіта і педагогічна думка в Україні. - 2010. - 1032 с.

6. Коваленко С. І. Історія зарубіжної педагогіки. Хрестоматія : [навч. посіб.] / Є. І. Коваленко, Н. І. Бєлкіна; заг. ред. С. І. Коваленко. - К. : Центр навчальної літератури, 2006. $-664 \mathrm{c}$.

7. Левківський М. В. Історія педагогіки : [навч. посіб.] / Михайло Васильович Левківський. - [4-те вид.]. - К. : Центр учбової літератури, 2011. - 190 с.

Стаття надійшла до редакції 27.05.2012 р.

\section{ВИВЧЕННЯ ПРОБЛЕМИ СПОЖИВЧОЇ КУЛЬТУРИ МАЙБУТНІХ УЧИТЕЛІВ ТЕХНОЛОГІЧНОЇ ОСВІТИ}

Вовк Н. В. Вивчення проблеми споживчої культури майбутніх учителів технологічної освіти.

У статті розглянуто питання вивчення проблеми формування споживчої культури майбутніх учителів технологічної освіти, визначено рівні та показники споживчої культури студентів. Культура споживання - ие сукупність стійких форм соиіальної взаємодї, закріплених у нормах і иінностях, засоби комунікації, які часто передаються від покоління до покоління. Вона виявлясться в існуванні відносно стійких форм, моделей споживання.

Ключові слова: культура, культура споживання.

Вовк Н. В. Изучение проблемы потребительской культуры будущих учителей технологического образования.

В статье рассмотрены вопросы изучения проблемы формирования потребительской культуры будущих учителей технологического образования, определены уровни и показатели потребительской культуры студентов. Культура потребления - это совокупность стойких форм соииального взаимодействия, закрепленных в нормах и иенностях, средства коммуникации, которые часто передаются от поколения к поколению. Она проявляется в существовании относительно стойких форм, моделей потребления.

Ключевые слова: культура, культура потребления.

Vovk N. A case study of consumer culture of the future teachers of technology education.

In article questions of studying of a problem of formation of consumer culture of future teachers of technological education are considered, levels and indicators of consumer culture of students are defined. The culture of consumption is a set of resistant forms of the social interaction fixed in norms and values, means of communication which are often transferred from generation to generation. It is shown in existence of rather resistant forms, consumption models.

Key words: culture, culture of consumption. 